\title{
Morphological measurements and body indices for Cuban Creole goats and their crossbreds
}

\author{
Edilberto Chacón ${ }^{1}$, Fernando Macedo ${ }^{2}$, Francisco Velázquez ${ }^{1}$, Samuel Rezende Paiva $^{3}$, \\ Eliecer Pineda ${ }^{1}$, Concepta McManus ${ }^{4,5}$
}

\footnotetext{
1 Facultad de Veterinária, Universidad de Granma, UDG, Carretera a Manzanillo, Km 17 1⁄2/2. Bayamo, Granma, Cuba.

2 Facultad de Veterinária, UdelaR, Alberto Lasplaces 1550 - CP 11 600, Montevideo, Uruguay.

${ }^{3}$ Embrapa - Recursos Genéticos e Biotecnologia, Parque Estação Biológica, Final W/5 Norte, 70770-900, Brasília, DF, Brasil.

${ }^{4}$ Faculdade de Agronomia e Medicina Veterinária, UnB, ICC Cento, Asa Norte, 70910 - 900, Brasília, DF, Brasil.

5 Departamento de Zootecnia, Universidade Federal do Rio Grande do Sul, Av. Bento Gonçalves 7712, Porto Alegre, Rio Grande do Sul, 91540-000.
}

\begin{abstract}
In this work, linear body measures were taken and production indices calculated for 100 Cuban Creole goats and 100 crossbred goats in order to aid in the characterization of animal genetic resources in Cuba. Low variation was found for all indices of the Creole goats, showing homogeneity between the groups of animals studied. Most of the functional indices are related to the milk biotype which is in agreement the possible origin of the breed from animals of the Iberian Peninsula and Canary Islands. The crossbreds were more varied, mostly due to undesigned disorganized crossing. These data may help in identifying a commercial niche for the breed and contribute to in situ conservation of the Cuban Creole goat.
\end{abstract}

Key Words: animal genetic resources, Capra hircus, conservation

\section{Introduction}

In recent years, goats from Cuban Creole breed which was widely distributed over the territory of Cuba, had its numbers drastically reduced due to the introduction of exotic breeds, considered by some people as more productive. This, in addition to lack of subjective information on the breed, led to it being registered as in danger of extinction according to the Cuban Report sent to the Food and Agriculture Organization of the United Nations (FAO, 2003).

Nowadays, this breed can be found in the eastern mountainous region of the country, where $69.9 \%$ of all goats of the nation are found. In this region, goat farming is important for the local economy. The cooperatives in the region are made up of small farms based on extensive farming in vast mountainous areas (Chacón et al., 2006). The need to conserve the Cuban Creole is vital to maintain genetic integrity, as well as to use its unique rustic qualities in commercial crosses.

One of the difficulties in conserving a genetic resource is the lack of its characterization and knowledge of the best production system for raising it. When little is known about a resource, its identity as a genetic group, its production, reproduction and adaptation potential, it is more difficult to find a market niche in the production system. Phenotypic characterization is therefore an important step in a conservation program, for breed identification and classification in ways that farming communities could be related (Dossa et al., 2007; Mwacharo et al., 2006).

Although conformation is related to performance, selection should be directed to ensure the breed does not lose its characteristics attained through natural selection (Santos et al., 1995). According to Giannoni (1988), the affirmation that 'frame predicts function' is somehow generic, as the performance of horses is influenced by morphological, physiological, and psychic factors, as well as by the environment. Therefore, frame is only an indication of the production value of the animal. Conformation and performance traits are heritable and influenced by environmental factors (Miserani et al., 2002).

Desirable body conformation, from the meat production viewpoint, is such a complex character that little progress has been made in reducing it to a single corporal measurement which can be taken on the live animal. Therefore, body conformation score, which is highly subjective and has low heritability, has been widely used. But, with the introduction of indices from body measurements, objective assessment of body conformation from the stand point of type may be relatively easier (Mwacharo et al., 2006). Thus, the objective of this study was to describe production indices for the Cuban Creole goat. 


\section{Material and Methods}

Phenotypic measurements were taken on 100 Cuban Creole adult female goats and on 100 of their crossbreds (mostly Anglo-Nubian type), on many farms on the Sierra Maestra, in the eastern region of Cuba (Table 1). The mountain range is $250 \mathrm{~km}$ long and $60 \mathrm{~km}$ wide and varies from 300 to $1,500 \mathrm{~m}$ above sea level. It is the largest mountain range in the country and has a subtropical climate, with mean annual temperatures of $28^{\circ} \mathrm{C}$ and relative humidity of $80 \%$. In this region, there are two well defined seasons: rainy season (May - October) and dry season (November-April). Except in the mountains, the climate of Cuba is semitropical or temperate. The average minimum temperature is $21^{\circ} \mathrm{C}$ and the average maximum temperature is $27^{\circ} \mathrm{C}$. The amount of rainfall varies from year to year and droughts are also common. The mountain areas have an average precipitation of more than $1,800 \mathrm{~mm}$, while most of the lowland area has from 900 to $1,400 \mathrm{~mm}$ annually. The slopes are very steep and there is abundant vegetation with predominantly leguminous shrubs, undergrowth and natural pastures traditionally used in animal feeding.

Both small and medium sized farms use extensive production systems with continuous grazing on open mountainous ranges due to the lack of territorial divisions, creating a single flock. Each breeder chooses the type of suckling, most kids staying with the dam until weaning. The male kids are mostly fattened for meat production with the larger ones selected for reproduction.

Data were collected from September 2004 to March 2005. Animals were classified as pure or crossed based on national and local (flock history) criteria as well for basic qualitative traits (horns, coat color, ear shape, mucus membrane color, beard). Adult animals aged three years or more were measured on small ( 3 to 15 animals) and medium (16 to 30 animals) flocks. Measurements of 15 characters (withers height, rump height, body length, sternum height, body depth, wither width, chest width, rump width, head width, rump length, head length, face length, heart girth, cannon bone circumference, muzzle diameter) were taken by using a metric tape, hipometer and paquimeter (Figure 1).

From these measurements, 22 conformation indices were calculated according to Agraz García (1981), Lopez et al. (1992), Salako (2006), Simões (1979), Martin-Rosset (1983), Torres \& Jardim (1987), Ribeiro (1988) and Santos et al. (1995):

(1) Cephalic (IC) $=$ Head width $\times 100 /$ Head length;

(2) Body (IB): Body length $\times 100$ / Heart girth: When this measure is greater than 0.90 , the animal is longiline; between 0.86 and 0.88 is medigline, and less than 0.85 , it is brevigline;

(3) Proportionality (IPr): Shoulder height $\times 100$ / Body length;

(4) Pelvic (IP): Rump width $\times 100$ / Rump length;

(5) Weight 1: Body length $\times$ body depth $\times$ (hip width + chest width)/2) /1050;

(6) Weight 2 (W2) $=\mathrm{HG}^{3 * 80}$. Weight above $45 \mathrm{~kg}$ correspond to large or hypermetric animals, between 35 and $55 \mathrm{~kg}$ medium or eumetric animal and less than $35 \mathrm{~kg}$, small or elipometric animals;

(7) Weight 3: Mohammed \& Amin (1997) $=W 3=(0.5 \times$ HG)-14.87;

(8) Weight 4: Singh \& Mishra (2004) - W4 $=(0.63 \times$ HG) - 19.5;

(9) Width slope (WS): rump width/chest width;

(10) Balance: (rump length $\times$ rump width)/ (chest depth $\times$ chest width);

(11) Metacarpo - costal (IMC): cannon bone perimeter $\times 100$ / rib distance;

(12) Transverse pelvic (IPT): rump width $\times 100 /$ rump height;

(13) Longitudinal pelvic (IPL): rump length $\times 100 /$ rump height;

(14) Relative depth of thorax (IPRT): chest depth $\times 100$ / wither height;

(15) Relative body index $(\mathrm{RBI})=\mathrm{BL} \times 100 /$ wither height. Also called length index;

(16) Dactyl thorax index (DTI) $=$ CC $/ H G$. The DTI may not be more than 10.5 in light animals, up to 10.8 in

Table 1 - Sampling information of Cuban Creole goats and their crosses

\begin{tabular}{llcc}
\hline Province & Flock & Number of Cuban Creoles goats & Number of crosses \\
\hline Santiago de Cuba & Finca “La Verdolaga” & - & 25 \\
& Finca “El Porvenir” & 10 & 15 \\
& Productores individuales & 22 & - \\
Granma $^{2}$ & Finca "Los Portugueses” & 9 & 13 \\
& CPA “Desembarco del Granma” & 8 & 17 \\
Holguín $^{3}$ & Escuela Preuniversitaria & 14 & 12 \\
\hline
\end{tabular}

${ }^{1}$ City of Santiago de Cuba; ${ }^{2}$ City of Guisa; ${ }^{3}$ City of Mayarí. 


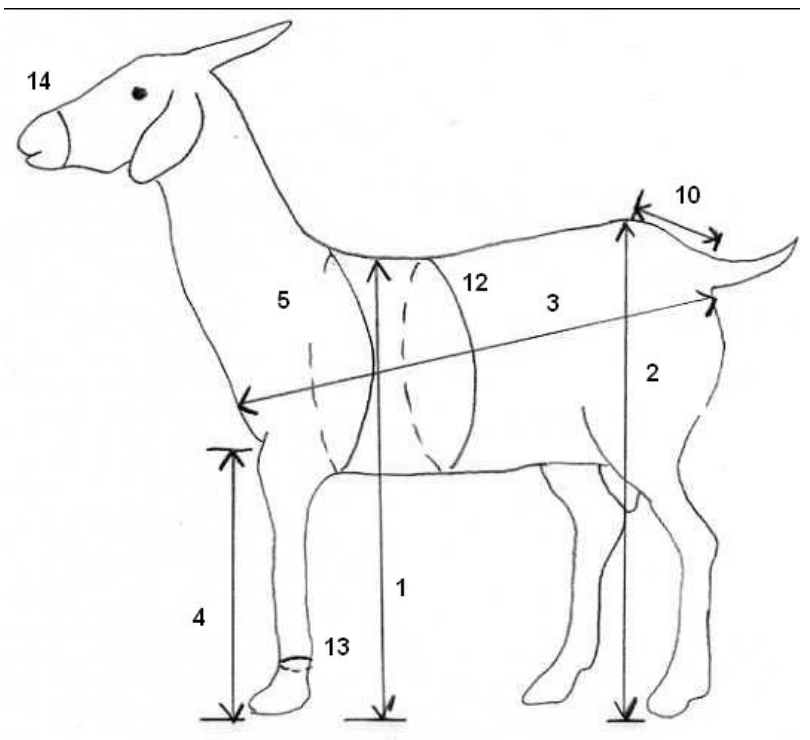

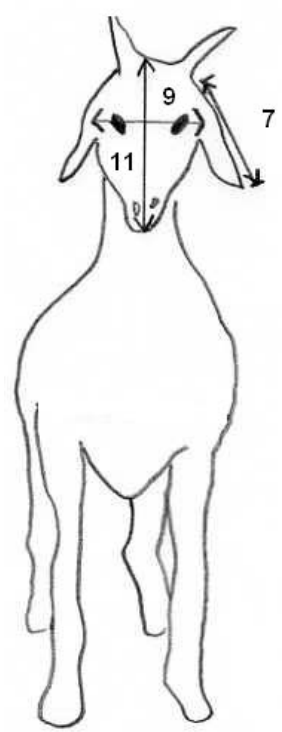
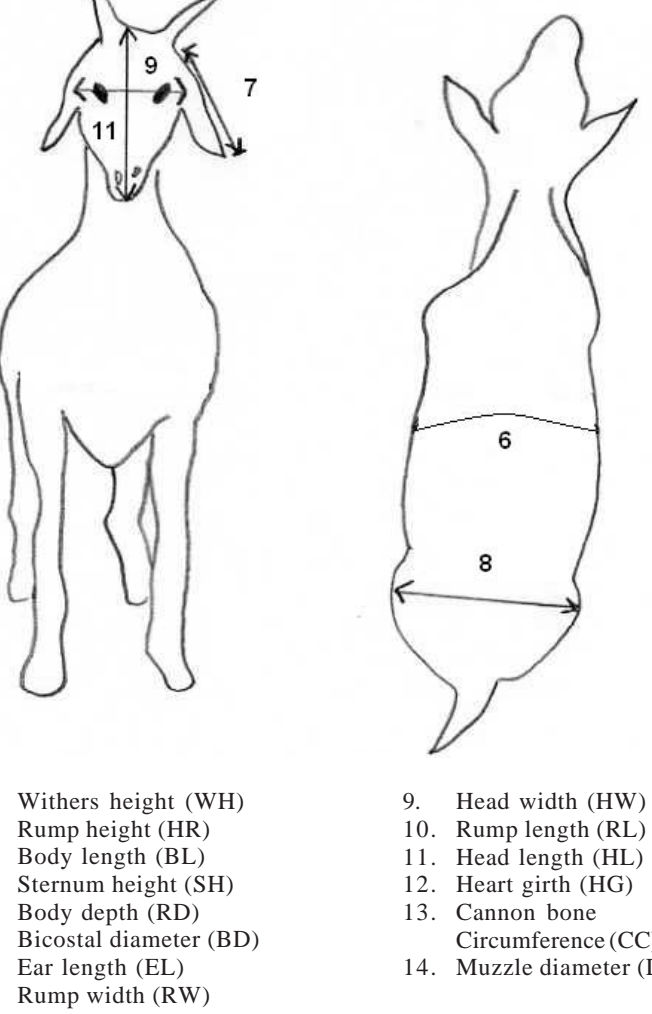

9. Head width (HW)

10. Rump length (RL)

11. Head length (HL)

12. Heart girth (HG)

13. Cannon bone

Circumference (CC)

14. Muzzle diameter (DH)

Figure 1 - Data collected on adult female Cuban Creole goats and their crosses.

intermediary; up to 11.0 in light meat animals and up to 11.5 in heavy meat type. This index also indicates thoracic development;

(17) Pectoral Index (PI): = ((HS + HR )/2)/SH. When the back height is less than the sternum height, the animal is considered "far from ground";

(18) Thoracic development $(\mathrm{TD})=$ HG/HS. This indicates thoracic development of the animal, with values above 1.2 indicating animals with good TD;
(19) Body ratio $(\mathrm{BR})=\mathrm{HS} / \mathrm{HR}$. If the withers are lower than the rump, the animal is low in front and vice versa.

(20) Baron \& Crevat (BC) $=\mathrm{HG}^{2} / \mathrm{HS}$. The greater the index, the more robust the animal, also called Conformation Index;

(21)Compact index $1(\mathrm{CI} 1)=(\mathrm{W} / \mathrm{HS}) / 100$; indicates how compact the animal is. Meat type animals have values above 3.15. Values close to 2.75 indicate dual purpose and close to 2.60 indicate animals more suitable for milk;

(22) Compact index 2 (CI2) = (W/(HS-1)]/100): This index also indicates the aptitude of the animal. Values above 9.5 indicate meat animals, from 8.0 to 9.5 , it indicates animals suitable for dual purpose and from 6.0 to 7.75 , it indicates milk animals.

All data were analyzed by using SAS procedures (SAS INSTITUTE $^{\circledR}$, v.9.2) including General Linear Model (GLM), Correlation (CORR), Principal Component (PRINCOMP), Frequency (FREQ), as well as the procedures for charts (CHART) and means (MEANS).

\section{Results and Discussion}

All the goats measured, both pure and crossbred, were horned (Table 2). Most Creole goats had straight ears. They varied in coat and mucus membrane color but had goatees, while the crossbreds had curly ears, less variable coat colors, generally black mucus membranes and may or may not have goatees.

Measurements such as wither height, body length, heart girth, rump height and width in the estimation of animal weight have been widely documented (Hassan \& Ciroma, 1992; Ozoje \& Herbert, 1987; Sowande \& Sobola, 2008), especially where weighing scales are not available. Cephalic dimensions have also been used as indicators of breed, origin and relationships within species (Jewel, 1963), while wither height has been used as an indicator of type in beef (Simon \& Buchanauer, 1993), because it indicates long bone growth. Type and function are considered better indicators of the usefulness of the animal than weight (Alberti et al., 2008). The weight itself is limited without some qualification, and probably quantification of associated type and conformation. Alderson (1999) reported that single linear measurements are more relevant for on-farm within-herd use. This is probably because of the reported significant influence of husbandry system on certain body measurements. However, different combinations of the measurements will likely be more useful.

No significant differences $(\mathrm{p}<0.05)$ were found between flocks or interaction between breed and flock. In general, crossbred animals are significantly larger than purebred 
Creole (Table 3). The breed normally used by breeders for crossbreeding is the Anglo Nubian, which is a larger animal. The main income for the breeders from these animals is from the sale of meat, so conformation and weight are important factors and this is why the Anglo-Nubian became popular in the region. The larger animal also has implications for maintenance requirements, as well as for adaptation to local conditions which should be taken into consideration when examining the production system.

The means for both purebreds and crosses are below those for commercial breeds such as Alpine and Saanen (Manfredi et al., 2001), Creole goats in Patagonia (Lanari et al., 2003) and Andalusian native breeds (Herrera et al., 1996). Compared with Moxotó animals in Brazil (Ribeiro et al., 2004), these animals have shorter bodies, but are taller and have higher heart girths. Measures were similar for Creole goats and their crosses in Mexico (Vargas et al., 2007).

Table 2 - Phenotypic traits of Cuban Creole goats and their crossbreds

\begin{tabular}{llcc}
\hline Variable & Type & Cross \% & Creole \% \\
\hline Horns & Presence & 100 & 100 \\
& Absence & 0.0 & 0.0 \\
Ear shape & Straight & 0.0 & 71.4 \\
& Semi-straight & 31.2 & 28.6 \\
Coat color & Curly & 68.8 & 0.0 \\
& 1 color & 53.1 & 28.0 \\
Mucus membrane color & 2 color & 46.9 & 43.5 \\
& 3 color & 0.0 & 28.5 \\
Beard & Black & 65.7 & 57.2 \\
& Pink & 34.3 & 42.8 \\
& Presence & 62.0 & 100 \\
& Absence & 38.0 & 0.0 \\
\hline
\end{tabular}

Based on these measurements, these goats may be considered medium sized (Devendra \& McLeroy, 1982) which are common in naturalized populations (Vargas et al., 2007). Studies showed that under natural conditions, indigenous breeds may suffer from vitamin and mineral deficiencies, as well as limitations in food quantity and quality which may affect linear body measurements (Kadim et al., 2006).

The coefficients of variation (CV) were low and in accordance with those found in other studies in sheep (Janssens \& Vandepitte, 2004), horses (Miserani et al., 2002, McManus et al., 2005) and goats (Herrera et al., 1996).

In general, correlations between the linear traits were medium, except for those involving RD and CL (Table 4). This is to be expected as animals that were large for one trait tend to be large for others. Coat length and rib diameter are the exceptions. This pattern was confirmed by a multivariate analysis where $49 \%$ of the variation between traits is explained by the first two autovectors (Figure 2). The second autovector shows a subgroup of animals that are wide hiped and large chested, but short.

Most indices showed low variation for the Creole breed (Table 5). The crossbreds showed higher variation for most indices, probably due to disorganized crossing. The highest coefficient of variation in the Creole breed was for the metacarpus costal index (10.23) and the lowest for relative depth of the body ratio (1.05), while for the crossbreds, the highest coefficient was for weight 2 (15.19) and the lowest for body ratio (4.60).

Indices show that the withers was slightly lower than the rump in both genetic groups (0.93) although not very unbalanced, which is an important trait for the health and

Table 3 - Linear body measurements in Cuban Creole goats and their crossbreds

\begin{tabular}{|c|c|c|c|c|c|c|c|}
\hline \multirow[b]{2}{*}{ Trait } & \multicolumn{3}{|c|}{ Creole } & \multicolumn{3}{|c|}{ Crossbred } & \multirow{2}{*}{$\begin{array}{c}\text { Difference } \\
\text { between means }\end{array}$} \\
\hline & Mean $(\mathrm{cm})$ & $\mathrm{CV}$ & Std & Mean $(\mathrm{cm})$ & Std & & \\
\hline Head length & 17.71 & 5.06 & 0.90 & 18.98 & 5.87 & 1.11 & $* * *$ \\
\hline Head width & 11.24 & 2.14 & 0.24 & 11.71 & 5.22 & 0.61 & $* * *$ \\
\hline Wither height & 60.97 & 2.61 & 1.59 & 64.53 & 5.02 & 3.24 & $* * *$ \\
\hline Rump height & 63.15 & 2.43 & 1.54 & 66.63 & 4.89 & 3.26 & $* * *$ \\
\hline Body length & 65.54 & 5.33 & 3.49 & 67.32 & 3.34 & 2.25 & $* * *$ \\
\hline Rump length & 18.15 & 5.03 & 0.91 & 18.61 & 9.23 & 1.72 & $*$ \\
\hline Rump width & 13.78 & 5.00 & 0.69 & 14.53 & 6.22 & 0.90 & $* * *$ \\
\hline Heart girth & 76.87 & 1.58 & 1.22 & 82.33 & 5.40 & 4.45 & $* * *$ \\
\hline Cannon bone circumference & 7.36 & 4.91 & 0.36 & 7.52 & 8.09 & 0.61 & $*$ \\
\hline Rib diameter & 14.15 & 7.93 & 1.12 & 14.65 & 6.12 & 0.90 & $* * *$ \\
\hline Sternum height & 31.92 & 4.66 & 1.49 & 34.16 & 10.73 & 3.67 & $* * *$ \\
\hline Chest width & 16.36 & 6.76 & 1.11 & 16.86 & 6.18 & 1.04 & $* * *$ \\
\hline Muzzle diameter & 23.91 & 1.59 & 0.38 & 24.59 & 8.20 & 2.02 & $* * *$ \\
\hline Ear length & 12.68 & 6.17 & 0.78 & 15.63 & 9.66 & 1.51 & $* * *$ \\
\hline Coat length & 3.14 & 9.65 & 0.30 & 2.99 & 22.07 & 0.66 & $\mathrm{P}<0.06$ \\
\hline Body depth & 29.04 & 2.81 & 0.82 & 30.37 & 8.50 & 2.58 & $* * *$ \\
\hline
\end{tabular}

*** $\mathrm{P}<0.001 ; * \mathrm{P}<0.05 ; \mathrm{CV}=$ coefficient of variation; $\mathrm{Std}=$ standard deviation. 
resistance of the animals, with $\mathrm{BC}$ indicating that the Creole were thinner animals than crossbreds. Compact index indicates that the animals were more suited for milk production but they had good thoracic development. This is important for the animals in terms of fitness, good respiratory system, especially in higher altitudes. There should be a balance between the height, body length and heart girth since that imbalance in its gravity center may affect its ability to balance on rocky ground. The DTI also indicates lightly built animals. PI indicates that the sternum was almost half the back height of the animal. Body length was marginally greater than wither height (RBI) but the IB indicates breviligne animals. The overall body shape is referred to as conformation. It is basically the result of many heritable traits, although environmental factors help shape the body of the animal.

The Cephalic index (IC) for Creole animals (63.65) showed a braquicephalic tendency. The IB (85.29), IPr (93.19) and IP (76.00) are related to the proportionality of the animal as a whole. An average animal is breviline, sublongiline, with a tendency towards a rectangular pelvis. In the crossbreds the IC (61.83) was slightly larger insomuch as these animals have a longer head. The IPr (95.90) was greater due to taller shoulders and IP (78.62) indicates that the shoulder was closer to a square. Body ratio (BR) indicates that both groups were slightly lower at the withers than the rump.

Although the DTI and IPL were significantly different between the two groups, it is not possible to assert that the crossbreds were more productive than the purebreds. They simply had a large morphological structure. The low variation in the descriptive indices of the two genetic groups is in agreement with other studies in India native goats (Sarma, 2006) and sheep from Nigeria (Salako, 2006).

Most indices showed significant differences between Creole and crossbred animals. The indices are considered an option for assessment of weight because they incorporate measures of desirable conformation, namely, length and balance (Alderson, 1999). Salako (2006) suggested that indices that are produced from measurements that are more closely associated with bone growth such as foreleg length, height slope and length index (RBI) are more appropriate for assessment of type. Assessment of type by using body measurements is more objective than those obtained by

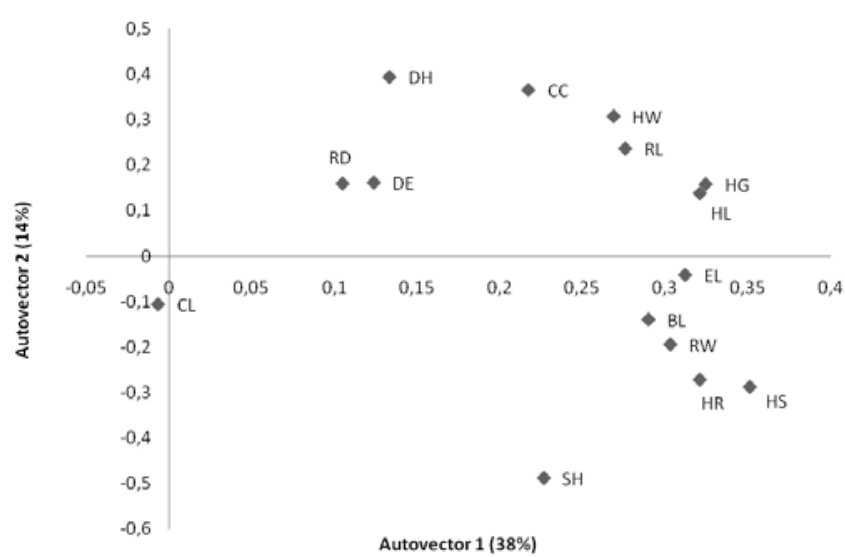

$\mathrm{CL}=$ coat length $\mathrm{RD}=$ rib diameter $\mathrm{DH}=$ muzzle diameter; $\mathrm{DE}=$ chest width $\mathrm{CC}$ = circumference; $\mathrm{HW}=$ head width; RL = rump length; HG = heart girth; HL = head length; $\mathrm{EL}$ = ear length; $\mathrm{BL}=$ body length; $\mathrm{RW}=$ rump width; $\mathrm{HR}=$ rump height; $\mathrm{HS}=$ wither height; $\mathrm{SH}=$ sternum height.

Figure 2 - First two autovectors for linear body measurements in Cuban Creole goats and their crossbreds.

Table 4 - Correlations between linear body measurements in Cuban Creole goats and their crossbreds

\begin{tabular}{|c|c|c|c|c|c|c|c|c|c|c|c|c|c|c|c|}
\hline & $\mathrm{HL}$ & HW & HS & HR & $\mathrm{BL}$ & $\mathrm{RL}$ & RW & HG & CC & $\mathrm{RD}$ & $\mathrm{SH}$ & $\mathrm{DE}$ & DH & EL & CL \\
\hline HW & 0.49 & & & & & & & & & & & & & & \\
\hline HS & 0.49 & 0.47 & & & & & & & & & & & & & \\
\hline HR & 0.41 & 0.35 & 0.76 & & & & & & & & & & & & \\
\hline BL & 0.58 & 0.23 & 0.49 & 0.57 & & & & & & & & & & & \\
\hline RL & 0.58 & 0.43 & 0.39 & 0.34 & 0.52 & & & & & & & & & & \\
\hline RW & 0.48 & 0.29 & 0.66 & 0.58 & 0.59 & 0.51 & & & & & & & & & \\
\hline HG & 0.56 & 0.58 & 0.60 & 0.59 & 0.33 & 0.63 & 0.45 & & & & & & & & \\
\hline CC & 0.37 & 0.59 & 0.35 & 0.21 & 0.28 & 0.44 & 0.26 & 0.36 & & & & & & & \\
\hline RD & 0.28 & 0.18 & 0.09 & 0.09 & 0.29 & 0.13 & 0.00 & 0.10 & 0.07 & & & & & & \\
\hline SH & 0.32 & 0.19 & 0.78 & 0.56 & 0.37 & 0.06 & 0.37 & 0.25 & 0.04 & 0.06 & & & & & \\
\hline $\mathrm{DE}$ & 0.38 & 0.24 & 0.14 & 0.06 & 0.16 & 0.06 & 0.19 & 0.12 & 0.13 & 0.25 & 0.11 & & & & \\
\hline DH & 0.21 & 0.29 & 0.12 & 0.19 & 0.04 & 0.21 & 0.06 & 0.39 & 0.31 & 0.06 & -0.06 & 0.09 & & & \\
\hline EL & 0.53 & 0.38 & 0.60 & 0.59 & 0.43 & 0.29 & 0.51 & 0.59 & 0.28 & 0.24 & 0.40 & 0.26 & 0.30 & & \\
\hline CL & -0.06 & 0.07 & 0.08 & -0.04 & -0.00 & -0.01 & 0.06 & -0.07 & 0.04 & -0.09 & 0.06 & -0.12 & -0.02 & -0.10 & \\
\hline $\mathrm{BD}$ & 0.28 & 0.45 & 0.38 & 0.34 & 0.20 & 0.51 & 0.47 & 0.54 & 0.47 & 0.06 & -0.28 & 0.06 & 0.28 & 0.33 & 0.0 \\
\hline HL & HW & HS & HR & BL & RL & RW & HG & CC & RD & SH & $\mathrm{DE}$ & DH & EL & CL & \\
\hline
\end{tabular}

$\mathrm{HL}$ = head length; HW = head width; HS = wither height; HR = rump height; $\mathrm{BL}$ = body length; RL = rump length; RW = rump width; HG = heart girth; CC = circumference; $\mathrm{RD}=$ rib diameter; $\mathrm{SH}=$ sternum height; $\mathrm{DE}=$ chest width; $\mathrm{DH}=$ muzzle diameter; $\mathrm{EL}=$ ear length; $\mathrm{CL}=\mathrm{coat}$ length; $\mathrm{BD}=$ body depth . 
Table 5 - Body indices for Cuban Creole goats and their crossbreds

\begin{tabular}{|c|c|c|c|c|c|c|c|}
\hline \multirow[b]{2}{*}{ Index } & \multicolumn{3}{|c|}{ Creole } & \multicolumn{3}{|c|}{ Crossbred } & \multirow{2}{*}{$\begin{array}{c}\text { Difference } \\
\text { between means }\end{array}$} \\
\hline & Mean & $\mathrm{CV}$ & Std & Mean & $\mathrm{CV}$ & Std & \\
\hline Cephalic & 63.65 & 5.48 & 3.49 & 61.83 & 5.82 & 3.60 & $* * *$ \\
\hline Body & 85.29 & 5.57 & 4.75 & 81.96 & 5.48 & 4.49 & $* * *$ \\
\hline Proportionality & 93.19 & 4.05 & 3.77 & 95.90 & 4.92 & 4.72 & $* * *$ \\
\hline Pelvic & 76.00 & 4.61 & 3.50 & 78.62 & 9.59 & 7.54 & $* *$ \\
\hline Metacarpus costal & 52.40 & 10.23 & 5.36 & 51.47 & 9.01 & 4.64 & ns \\
\hline Pelvic transverse & 21.81 & 3.72 & 0.81 & 21.83 & 6.39 & 1.39 & ns \\
\hline Pelvic longitudinal & 28.73 & 3.98 & 1.14 & 27.97 & 9.67 & 2.71 & $*$ \\
\hline Relative depth of thorax & 47.66 & 2.98 & 1.42 & 47.13 & 8.88 & 4.19 & ns \\
\hline Weight 1 & 26.26 & 6.85 & 1.80 & 29.27 & 11.93 & 3.49 & $* * *$ \\
\hline Weight 2 & 36.36 & 4.72 & 1.72 & 45.02 & 15.19 & 6.84 & $* * *$ \\
\hline Weight 3 & 23.56 & 2.58 & 0.61 & 26.29 & 8.46 & 2.22 & $* * *$ \\
\hline Weight 4 & 28.92 & 2.65 & 0.77 & 32.36 & 8.66 & 2.80 & $* * *$ \\
\hline Width slope & 84.50 & 6.91 & 5.84 & 86.52 & 8.91 & 7.71 & $*$ \\
\hline Balance & 0.53 & 9.55 & 0.05 & 0.53 & 12.73 & 0.07 & ns \\
\hline Relative body & 1.07 & 4.23 & 0.45 & 1.05 & 4.76 & 0.50 & $* * *$ \\
\hline Dactyl thorax & 9.58 & 5.17 & 0.50 & 9.15 & 7.59 & 0.69 & $* * *$ \\
\hline Pectoral index & 1.95 & 2.75 & 0.05 & 1.94 & 9.11 & 0.18 & ns \\
\hline Thoracic development & 1.26 & 3.00 & 0.38 & 1.28 & 5.65 & 0.72 & $\mathrm{P}<0.06$ \\
\hline Body ratio & 0.97 & 1.05 & 0.01 & 0.97 & 4.60 & 0.04 & ns \\
\hline Baron \& Crevat & 97.01 & 4.08 & 3.96 & 105.37 & 9.63 & 10.15 & $* * *$ \\
\hline Compact index 1 & 5.20 & 5.40 & 0.32 & 6.97 & 14.04 & 0.97 & $* * *$ \\
\hline Compact index 2 & 6.07 & 5.42 & 0.32 & 7.19 & 14.03 & 0.99 & $* * *$ \\
\hline
\end{tabular}

$* * * \mathrm{p}<0.001 ; * * \mathrm{p}<0.01 ;{ }^{*} \mathrm{p}<0.05 ; \mathrm{ns}=$ non-significant; $\mathrm{CV}=$ coefficient of variation; Std = standard deviation.

visual appraisal, though both are still inferior to 'function' as criteria for selecting breeding stock.

Although concepts of perfect conformation vary among breeds, all breed registries agree that the overall quality and balance of an animal should be symmetrical and proportional to its size (Martin et al., 1978).

Data from Argentinean Creole goats (Revidatti et al., 2007) showed lower values for IC $(38.9 \pm 3.2)$, IPr $(83.15 \pm 5.4)$ and IP $(70.0 \pm 5.1)$ and higher values for IB (85.8 \pm 5.9$)$. Females of Branca de Rasqueda breed from Catalunia had higher IPr $(101.40 \pm 6.66)$ and IP $(77.97 \pm 13.65)$ values and lower IC $(52.73 \pm 3.50)$ and IB (81.46 \pm 4.88 ) values (Carné et al., 2007). Lanari et al. (2003) also found slightly lower IC and IP with higher IB for Creole goats in Patagonia. This variability in conformation of these genetic groups may be related to differences in genetic aspects and different systems of rearing developed for goat production in the Americas.

In terms of the functional indices, IMC is linked to strength of the extremities in relation to body mass. Dactyl thorax index (DTI) gives an indication of how fine the skeleton is, so it is greater in meat than in milk type animals, in which an increment in cannon bone circumference presupposes an increase in body size (Peña et al., 1990). All values for IMC (52.40) as well as for DTI (9.58) are related to the milk biotype, in agreement with research carried out by Martinez et al. (2007), in which they found that the origin of the same breed, as in this paper was from milk type goats brought from the Iberian Peninsula and the Canary Islands. The IMC may be related to adaptive capacity of this breed in the environment where it is found.

Pelvic indices, both IPT (21.81) and IPL (28.73), showed that the Cuban creole breed have narrow hips with low meat production potential. Despite this, these animals are predominantly used by breeders for meat production. This was one of the contributing factors for the introduction of exotic breeds to improve carcass traits (Chacón et al., 2006). The milk production of this breed should be studied to identify its potential within the system and help to identify a commercial niche, as well as contribute for in situ conservation. More information on the breed would also help to implement structured crossbreeding systems and help to maintain purebred animals.

The relative depth of thorax (IPRT) (47.66) is an indirect measure of leg length, whereby higher indices for this trait correspond to animals with longer legs. According to Sastre (2003), animals with higher IPRT have higher kinetic capacity, being more adapted to plains and long treks with bodies further from the ground to avoid heat radiation. The IPRT indicates short members for the Cuban Creole, with a body close to the ground, which may correspond to its adaptations to mountainous terrain. The width slope and length indices are useful parameters for estimating balance, 
and they can be important in the assessment of functionality (Salako, 2006).

Four different formulae (weight 1, weight 2, weight 3 and weight 4) were used to estimate weight giving significantly different answers. As the correlations between weight 2 (W2), weight 3 (W3) and weight 4 (W4) were approximately 1 and because they were all based on a single measure (HG), only W1 and W2 remained in the analyses (Table 6). In general, the crossbreds were heavier than the purebreds in order that purebred weight was approximately $28.77 \mathrm{~kg}$ and crossbred $33.24 \mathrm{~kg}$. Given the divergence in estimated weights by the various indices, a study needs to be carried out to determine the best formula for this breed, since most farmers cannot afford weighing scales but have easy access to measuring tapes. Schwabe and Hall (1989) used a formula involving girth height and body length to describe weight whereas Alderson (1999) developed a system of linear measurements to provide an assessment of type in beef and overall value of an animal. Indices are often considered a superior option for assessment of weight because they incorporate measures of desirable conformation, such as large chests to suitable height measurements. They are expected to provide tested empirical alternative to the limited use of single measurements for the assessment of type, weight and function as well as enhance the ability of breeders to select potential breeding stock. They provide potential purchasers with a reliable evaluation of animals because the measurements are associated with production characteristics.

Adult body weights were rather lighter than AngloNubian goats in Rwanda (51.4 kg;Wilson \& Murayi, 1988), as well as native and commercial breeds in Mexico (Montaldo et al., 1995), but approximately the same as native Moxotó goats in Brazil (30.13 kg; Ribeiro et al., 2004).

Correlations among indices are, in general, low and frequently negative (Table 6). Those indices which used the same linear measurement as a base tended to have higher correlations, as expected. Similar correlations between linear traits have been found in horses in Brazil (Miserani et al., 2002; McManus et al., 2005) and sheep in Belguim (Janssens \& Vandepitte, 2004).

The first two autovectors for the indices, which explain $50 \%$ of the variation, showed that animals that have high BC, PI and TD tend to have low IB (Figure 3) while a subgroup had high RBI, Balance, IPL and low TD and IPR. The first autovector contrasts long thin animals with those that are more stocky and chesty, while the second contrasts short thin animals with taller more robust ones.

Performance, on the other hand, especially in function of meat production, can be assessed from body measurements such as chest width, hip width and chest depth, which are less closely associated with bone growth. These indices include width slope, balance, depth index and cumulative index (which include balance), in that order.

Table 6 - Correlations between body indices in Cuban Creole goats and their crossbreds

\begin{tabular}{|c|c|c|c|c|c|c|c|c|c|c|c|c|c|c|c|c|c|c|c|}
\hline & IC & IB & IPR & IP & IMC & IPT & IPL & IPRT & W 1 & IWS & Balance & RBI & DTI & P I & T D & BR & $\mathrm{BC}$ & W 2 & CI1 \\
\hline IB & 0.22 & & & & & & & & & & & & & & & & & & \\
\hline IPR & -0.26 & -0.62 & & & & & & & & & & & & & & & & & \\
\hline IP & 0.07 & -0.25 & -0.18 & & & & & & & & & & & & & & & & \\
\hline IMC & -0.21 & -0.09 & -0.08 & 0.26 & & & & & & & & & & & & & & & \\
\hline IPT & 0.20 & 0.13 & -0.06 & -0.26 & -0.01 & & & & & & & & & & & & & & \\
\hline IPL & 0.21 & -0.13 & -0.23 & 0.74 & 0.23 & 0.45 & & & & & & & & & & & & & \\
\hline IPRT & -0.16 & -0.26 & -0.20 & 0.26 & 0.22 & 0.18 & 0.37 & & & & & & & & & & & & \\
\hline W1 & 0.22 & -0.06 & -0.02 & 0.09 & 0.04 & 0.29 & 0.29 & 0.38 & & & & & & & & & & & \\
\hline IWS & 0.04 & 0.02 & 0.10 & -0.17 & 0.57 & 0.38 & 0.10 & 0.03 & 0.09 & & & & & & & & & & \\
\hline Balance & 0.28 & 0.10 & -0.10 & 0.22 & 0.40 & 0.32 & 0.42 & -0.27 & 0.00 & 0.77 & & & & & & & & & \\
\hline RBI & 0.28 & 0.63 & -1.00 & 0.20 & -0.05 & 0.08 & 0.25 & 0.19 & 0.03 & -0.08 & 0.13 & & & & & & & & \\
\hline DTI & -0.17 & 0.40 & -0.13 & 0.01 & 0.52 & 0.13 & 0.10 & 0.12 & 0.06 & -0.08 & -0.14 & 0.15 & & & & & & & \\
\hline P I & 0.16 & 0.26 & 0.20 & -0.26 & -0.22 & -0.18 & -0.37 & -1.00 & -0.38 & -0.03 & 0.27 & -0.19 & -0.12 & & & & & & \\
\hline T D & -0.17 & -0.64 & 0.17 & 0.60 & 0.10 & -0.68 & 0.08 & 0.10 & -0.12 & -0.40 & -0.25 & -0.17 & -0.28 & -0.10 & & & & & \\
\hline $\mathrm{BR}$ & 0.01 & -0.11 & 0.50 & -0.02 & 0.08 & 0.47 & 0.30 & -0.20 & 0.11 & 0.02 & 0.03 & -0.47 & 0.18 & 0.20 & -0.11 & & & & \\
\hline $\mathrm{BC}$ & 0.12 & -0.71 & 0.05 & 0.43 & 0.12 & -0.05 & 0.36 & 0.35 & 0.43 & 0.09 & 0.16 & -0.05 & -0.45 & -0.35 & 0.59 & -0.16 & & & \\
\hline W 2 & 0.18 & -0.64 & 0.30 & 0.27 & 0.16 & 0.00 & 0.24 & 0.11 & 0.61 & 0.25 & 0.27 & -0.29 & -0.42 & -0.11 & 0.42 & 0.06 & 0.88 & & \\
\hline CI1 & 0.15 & -0.70 & 0.14 & 0.37 & 0.14 & -0.04 & 0.31 & 0.27 & 0.52 & 0.15 & 0.21 & -0.14 & -0.45 & -0.27 & 0.54 & -0.09 & 0.98 & 0.95 & \\
\hline $\mathrm{CI} 2$ & 0.15 & -0.70 & 0.14 & 0.37 & 0.14 & -0.04 & 0.31 & 0.27 & 0.52 & 0.15 & 0.20 & -0.14 & -0.45 & -0.27 & 0.54 & -0.09 & 0.98 & 0.95 & 1.00 \\
\hline
\end{tabular}

IC = cephalic; IB = body; IPR = proportionality; IP = pelvic; IMC = metacarpus costal; IPT = pelvic transverse; IPL= pelvic longitudinal; IPRT= relative depth of thorax; $\mathrm{W} 1$ = weight 1 ; IWS = width slope; RBI = relative body; DTI = dactyl thorax; PI= pectoral index; $\mathrm{TD}=$ thoracic development; $\mathrm{BR}=$ body ratio; $\mathrm{BC}=\mathrm{Baron} \& \mathrm{Crevat}$; W2 = weight $2 ; \mathrm{CI} 1$ = compact index $1 ; \mathrm{CI} 2$ = compact index 2. 


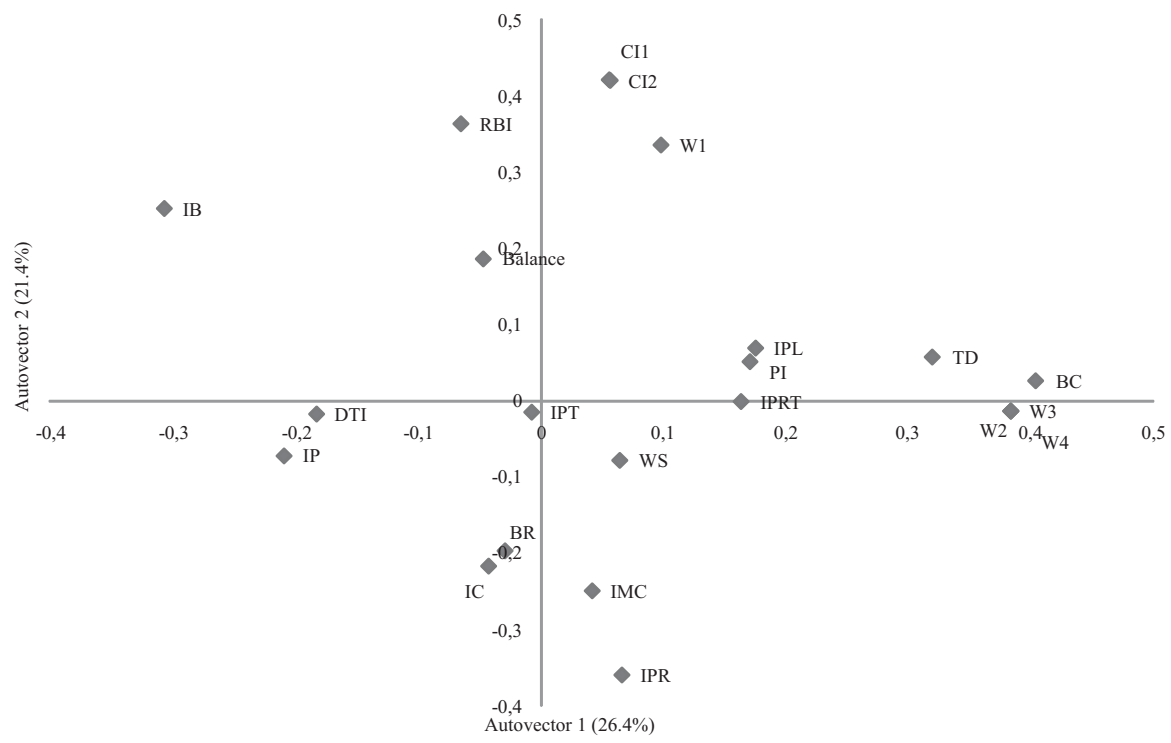

IB = body index; IP =pelvic index; DTI = dactyl thorax; BR = body ratio; IC = cephalic; RBI = relative body; IMC = metacarpus costal; IPR = proportionality; IPT = pelvic transverse; WS = width slope; IPRT = relative depth of thorax; $\mathrm{BR}=$ body ratio; PI =pectoral index; IPL = pelvic longitudinal; TD = thoracic development; $\mathrm{W} 1$ = weight 1 ; W2 = weight 2; W3 = weight 3; W4 = weight $4 ; \mathrm{BC}=$ Baron \& Crevat; CI1 = compact index 1; CI2 = compact index 2.

Figure 3 - First two autovectors for body indices in Cuban Creole goats and their crossbreds.

\section{Conclusions}

Cuban Creole goats is a medium sized animal. Its morphology corresponds to the milk type animal although it is used for meat production, confirming a possible common trend between the naturalized goats from South American and Caribbean. Crossbreeding results in larger and more robust animals.

\section{Acknowledgements}

Thanks to CAPES and CNPq (INCT-IGS) for scholarships and financial support. In particular, the authors would like to thank breeders of the Cuban Creole goat and people from the mountains of eastern Cuba, for the information and help for data collection.

\section{References}

AGRAZ, G.A.A. Cría y explotación de la cabra en América Latina. Buenos Aires: Hemisferio Sur, 1981. 482p.

ALBERTI, P.; PANEA, B.; SAÑUDO, C. et al. Live weight, body size and carcass characteristics of young bulls of fifteen European breeds. Livestock Science, v.114, p.19-30, 2008.

ALDERSON, G.L.H. The development of a system of linear measurements to provide an assessment of type and function of beef cattle. AGRI, v.25, p.45-55, 1999.

CARNÉ, S.; ROIG, N.; JORDANA, J. La cabra Blanca Rasquera: caracterización morfológica y faneróptica. Archivos de Zootecnia, v.215, p.319-330, 2007.

CHACÓN, M.E.; VELÁZQUEZ, R.F.; PÉREZ, P. et al. Estudio preliminar de los sistemas de explotación de la cabra criolla cubana. In: I Taller Iberoamericano sobre conservación y utilización sustentable de razas caprinas y ovinas locales en áreas marginales. Cochabamba, Bolivia. 2006, Anais... 2006.

DEVENDRA C.; MCLEROY, G.B. Goat and sheep production in the tropics. London: Longman, 1982. p.9-31.

DOSSA, L.; WOLLNY, C.; GAULY, M. Spatial variation in goat populations from Benin as revealed by multivariate analysis of morphological traits. Small Ruminant Research, v.73, p.150-159, 2007.

FOOD AND AGRICULTURE ORGANIZATION OF THE UNITED NATIONS - FAO. [2003]. Informe del país sobre la situación nacional de los recursos zoogenéticos en animales de granja. Available at: <http://dad.fao.org/cgi-bin/getblob.cgi>. Accessed on: Oct. 112010.

GIANNONI, M.A. Métodos de melhoramento genético e sistemas de acasalamentos aplicados aos eqüinos. Jaboticabal: FUNEP, 1988. 63p.

HASSAN, A.; CIROMA, A. Body weight measurement relationships in Nigerian Red Sokoto goats. In: BIENNIAL CONFERENCE OF THE SMALL RUMINANTS RESEARCH NETWORK, 1. ILRAD, 1992, Nairobi, Kenya. Proceedings... Nairobi, Kenya, 1992. p.491-49.

HERRERA, M.; RODERO, E.; GUTIÉRREZ, M.J. et al. Application of multifactorial discriminant analysis in the morphostructural differentiation of Andalusian caprine breeds. Small Ruminant Research, v.22, p.39-47, 1996.

JANSSENS, S.; VAMDEPITTE, W. Genetic parameters for body measurements and linear type traits in Belgian Blue du Maine, Suffolk and Texel sheep. Small Ruminant Research, v.54, p.13-24, 2004

JEWEL, P.A. Cattle from British archaeological sites. In: MOURANT, A.E.; ZEUNER, F.E. (Eds.) Man and cattle. London: Royal Anthropological Institute of Great Britain and Ireland, 1963. p.79-85.

KADIM, I.; MAHGOUB, O.; AL-AJMI, D. et al. Comparative effects of low levels of dietary cobalt and parenteral injections of Vitamin B12 on body dimensions in different breeds of Omani goats. Small Ruminant Research, v.66, p.244-252, 2006. 
LANARI, M.R.; TADDEO, H.R.; DOMINGO, E. et al. Phenotypic differentiation of exterior traits of Criollo goat population in Patagonia (Argentina). Archiv Tierzucht, v.46, p.347-356, 2003.

LÓPEZ, F.J.L.; ARGUELlO, H.A.; CAPOTE, A.J. et al. Contribution to the study of the black canary pig. Archivos de Zootecnia, v.41, p.531-536.1992.

MANFREDI, E.; PIACERE, A.; LAHAYE, P. et al. Genetic parameters of type appraisal in Saanen and Alpine goats. Livestock Production Science, v.70, p.183-189, 2001.

MARTIN, D.V.M.; MCMULLAN, W.C.; JOYCE, J.R. et al. Equine genetics \& Selection procedures. Texas: Equine Research, 1978. p.541.

MARTINEZ, M.A.; VEGA-PLA, J.L.; MENEZES, M.P.C. et al. Relaciones genéticas entre razas caprinas ibéricas y latinoamericanas. In: SIMPOSIO IBEROAMERICANO SOBRE CONSERVACION Y UTILIZACION DE RECURSOS ZOOGENETICOS, 8., 2007, Quevedo, Ecuador. Anais... Quevedo, 2007. (CD-ROM).

MARTIN-ROSSET, W. Particularites de la croissance et du development Ducheval. Reviu Bibliographique. Annales Zootechnie, v.32, n.1, p.373-380, 1983.

MCMANUS, C.M.; FALCÃO, R.A.; SPRITZE, A. et al. Caracterização morfológica de eqüinos da raça Campeiro. Revista Brasileira de Zootecnia, v.34, n.5, p.1553-1562, 2005.

MISERANI, M.G.; MCMANUS, C.; SANTOS, S.A. et al. Fatores que influem nas medidas lineares do cavalo Pantaneiro. Revista Brasileira de Zootecnia, v.31, n.1, p.335-341, 2002.

MOHAMMED, I.D.; AMIN, J.D. Estimating body weight from morphometric measurements of Sahel (Borno White) goats. Small Ruminant Research, v.24, p.1-5, 1997.

MONTALDO, H.; JUÁREZ, A.; BERRUECOS, J.M. et al. Performance of local goats and their backcrosses with several breeds in Mexico. Small Ruminant Research, v.16, p.97-105, 1995.

MWACHARO, J.M.; OKEYO, A.M.; KAMANDE, G.K. et al. The small East African shorthorn zebu cows in Kenya. In: Linear body measurements. Tropical Animal Health and Production, v.38, p.65-74. 2006.

OZOJE, M.O.; HERBERT, U. Linear measurements in West African Dwarf (WAD) and WAD* Red Sokoto goats. Nigerian Journal of Animal Production, v.24, p.13-19, 1987.

PEÑA, B.F.; DOMENECH, G.V.; APARICIO, R.F. et al. Estudio Biométrico en la raza ovina Segureña. Revista Archivo de zootecnia, v.39, p.253, 1990.

REVIDATTI, M.A.; PRIETO, P.N.; DE LA ROSA, S. et al. Cabras criollas de la región norte argentina. Estudio de variables e índices zoométricos. Archivos de Zootecnia, v.56, p.479-482, 2007.
RIBEIRO, D.B. O cavalo: raças, qualidades e defeitos. Rio de Janeiro: Globo Rural, 1988. 290p.

RIBEIRO, M.N.; OLIVEIRA, J.C.V.; ROCHA, L.L. et al. Caracterización, evaluación y conservación de caprinos Moxotó en el Estado de Pernambuco, Brasil. Archivos Latinoamericanos de Produccion Animal, v.12, p.54-58, 2004.

SALAKO, A.E. Application of morphological indices in the assessment of type and function in sheep. International Journal of Morphology, v.24, p.13-18, 2006.

SANTOS, S.A.; MAZZA, M.C.M.; SERENO, J.R.B. et al. Avaliação e conservação do cavalo Pantaneiro. Corumbá: EMBRAPA-CPAC, 1995. p.40.

SARMA, K. Morphological and craniometrical studies on the skull of kagani goat (Capra hircus) of Jammu Region. International Journal of Morphology, v.24, p.449-455, 2006.

SASTRE, H.J. Descripción, situación actual y estrategias de conservación de la raza bovina colombiana criolla Casanare. 2003. 330f. Tesis (Doctor en Veterinaria) Universidad de Córdoba - Córdoba, España.

SHWABE, A.E.; HALL, S.J.G. Dystocia in nine British breeds of cattle and its relationships to the dimensions of the dam and calf. The Veterinary Record, v.125, p.636-639, 1989.

SIMÕES, F. Mangalarga e o cavalo de sela brasileiro. 2.ed. São Paulo: Editora dos Criadores Ltda., 1979. p.35-37.

SIMON, D.L.; BUCHANAUER, D. Genetic diversity of European Livestock breeds. Wageningen: Wageningen Press, 1993. 582p.

SINGH, P.N.; MISHRA, A.K. Prediction of body weight using conformation traits in Barbari goats. Indian Journal of Small Ruminants, v.10, p.173, 2004.

SOWANDE, O.S.; SOBOLA, O.S. Body measurements of west African dwarf sheep as parameters for estimation of live weight. Tropical Animal Health and Production, v.40, p.433-439, 2008.

STATISTICAL ANALYSIS SYSTEM - SAS. User's guide. 8.ed. Cary: SAS Inst. Inc., 1999. 295p.

TORRES, A.P.; JARDIM, W.R. Raças de cavalos. Criação do cavalo e outros eqüinos. 3.ed. São Paulo: Nobel, 1987. p.654.

VARGAS, S.; LARBI, L.; SÁNCHEZ, M. Analysis of size and conformation of native Creole goat breeds and crossbreds used in smallholder agrosilvopastoral systems in Puebla, Mexico. Tropical Animal Health and Production, v.39, p.279-286. 2007.

WILSON, R.T.; MURAYI, T. Productivity of the Small East African goat and its crosses with the Anglo - Nubian and the Alpine in Rwanda. Tropical Animal Health and Production, v.20, p.219-228, 1988. 